\title{
Feeling Like a Group After a Natural Disaster: Common Ingroup Identity and Relations with Outgroup Victims among Majority and Minority Young Children
}

\begin{abstract}
We conducted a field study to test whether the common ingroup identity model (Gaertner \& Dovidio, 2000) could be a useful tool to improve intergroup relations in the aftermath of a natural disaster. Participants were majority (Italian) and minority (immigrant) elementary school children $(N=517)$ living in the area struck by powerful earthquakes in May 2012. Results revealed that, among majority children, the perceived external threat represented by the earthquake was associated with greater perceptions of belonging to a common ingroup including both ingroup and outgroup. In turn, heightened one-group perceptions were associated with greater willingness to meet and help outgroup victims, both directly and indirectly via more positive outgroup attitudes. Among immigrant children, perceived disaster threat was not associated with any of the dependent variables; one-group perceptions were positively associated with outgroup attitudes, helping and contact intentions towards outgroup victims. Thus, one-group perceptions after a natural disaster may promote more positive and supporting relations between the majority and the minority group. We discuss the theoretical and practical implications of findings.
\end{abstract}

Keywords: natural disasters, earthquake, intergroup relations, common ingroup identity model, helping behavioural intentions. 


\section{NATURAL DISASTERS AND COMMON INGROUP IDENTITY}

Modena was the city most affected by the two powerful earthquakes that struck Emilia-Romagna, a Northern Italian region, in May 2012, and that caused considerable structural and psychological damage, not to mention the death of 27 people. Weaker tremors continued to frighten the local population for several months. Traumatic events such as earthquakes have devastating consequences for people, especially children. Indeed, children may be less prepared than adults to face these traumatic events and suffer to a high degree. Consistently, children who are exposed to disasters typically report psychological distress symptoms, which interfere with their emotional and cognitive functioning (Gurwitch, Kees, \& Becker, 2002; Kar \& Bastia, 2006; La Greca, Silverman, Lai, \& Jaccard, 2010). This was also true in the context examined. Indeed, among elementary school children aged 6-10 years exposed to the earthquake that struck Emilia Romagna in 2012, Cadamuro and Versari (2012) found evidence of high levels of Post Traumatic Stress Disorder, a dangerous health disorder that can severely impair children's psychological functioning (Furr, Corner, Edmunds, \& Kendall, 2010). In such a context, social support from peers was found to be a key factor in helping children to recover from the consequences of the earthquake (Cadamuro, Versari, Vezzali, Giovannini, \& Trifiletti, in press).

Social support from peers may be especially difficult to obtain within multicultural contexts, where relationships between majority and minority members may be seriously affected by the threat represented by the disaster. However, threat may also have unexpected effects. In particular, we wondered whether disaster threat might tangentially produce beneficial effects among children involved in the traumatic event. Specifically, is it possible that feeling threatened by the earthquake helps children belonging to different ethnic groups to feel as a single group, and therefore to go 


\section{NATURAL DISASTERS AND COMMON INGROUP IDENTITY}

beyond traditional rivalries and improve interethnic relations? Our aim was to test for the first time the common ingroup identity model (CIIM; Gaertner \& Dovidio, 2000, 2012), a popular prejudice-reduction approach, as a mechanism to improve intergroup relations following an earthquake. In addition to outgroup attitudes, we also tested effects on intergroup contact and helping behavioural intentions, which are crucial in order to strengthen community ties and react more effectively to the traumatic event.

Although not numerous, there are some studies providing an initial case that exposure to natural disasters may influence intergroup relations within multicultural settings. In general, they show that prejudice may seriously affect responses to natural disasters, by worsening intergroup relations (Cuddy, Rock, \& Norton, 2007; Eccleston, Kaiser, \& Kraynak, 2010; Kaiser, Eccleston, \& Hagiwara, 2008). However, none of these studies examined intergroup responses to disasters among individuals actually involved in them, for whom community reactions and reciprocal helping may be especially important for coping with the negative event. In addition, previous studies did not test effects on intergroup relations among young children. Since children may be especially vulnerable to the detrimental consequences of disasters, they should be a primary target of interventions designed to improve intergroup relations in the aftermath of natural disasters.

In the next paragraph, after presenting evidence for the CIIM (Gaertner \& Dovidio, 2000, 2012), we will discuss the rationale underlying the hypothesis that responses to the threat caused by natural disasters may improve intergroup relations via stronger one-group perceptions.

The common ingroup identity model 


\section{NATURAL DISASTERS AND COMMON INGROUP IDENTITY}

According to the CIIM (Gaertner \& Dovidio, 2000, 2012), conditions that foster perceptions that ingroup and outgroup members are included in a common superordinate category, instead of belonging to distinct groups, will improve intergroup relations. Intergroup bias originating from categorization in ingroup and outgroup should thus be reduced, because former outgroup members are now accorded the status and the privileges of ingroup membership.

Basic predictions of the CIIM have been supported by an impressive number of experimental (e.g., Dovidio et al., 1997; Gaertner, Mann, Murrell, \& Dovidio, 1989; Gonzalez \& Brown, 2003; Hall, Crisp, \& Suen, 2009; Riek, Mania, Gaertner, McDonald, \& Lamoreaux, 2010, Study 2), longitudinal (Levin, Sinclair, Sidanius, \& Van Laar, 2009; Schofield, Hausmann, Ye, \& Woods, 2010), and cross-sectional (e.g., Capozza, Trifiletti, Vezzali, \& Favara, 2013; Capozza, Vezzali, Trifiletti, Falvo, \& Favara, 2010; Gaertner, Rust, Dovidio, Bachman, \& Anastasio, 1994) studies. Moreover, there are indications that the CIIM is also an effective prejudice-reduction strategy among young children (Guerra, Rebelo, Monteiro, \& Gaertner, 2013; Guerra et al., 2010). Guerra and colleagues (2010) experimentally manipulated the endorsement of group representations among majority (European-Portuguese) and minority (AfricanPortuguese) elementary school children. Results showed that bias in resource allocations and competence ratings towards outgroup classmates was lower when a superordinate identity was salient, compared to when children perceived to belong to distinct groups (for a similar intervention, see Guerra et al., 2013; for evidence supporting the CIIM among young children in the context of an imagined intergroup interaction, see Vezzali et al., 2014). 


\section{NATURAL DISASTERS AND COMMON INGROUP IDENTITY}

According to the CIIM (Gaertner \& Dovidio, 2000, 2012), there are several conditions that can enhance the salience of a superordinate representation, such as perceiving that the ingroup shares a common fate with the outgroup or that there is a threat directed at the superordinate group. Indeed, an external threat directed simultaneously at ingroup and outgroup members should reduce perceptions of intergroup dissimilarities and, in turn, improve attitudes towards former outgroup members.

We are not aware of any study testing the path from external threat to outgroup attitudes via a common ingroup identity. Indirect support for our hypothesis was provided by Dovidio et al. (2004, Study 2). The authors found that White university students perceived a Black individual as a member of their own group and displayed reduced prejudice when they were presented with a threat (a terrorist attack) directed at all Americans independently of race rather than when they were exposed to a threat directed at only the White ingroup. The authors reasoned that an external threat would create an inclusive representation of the ingroup and outgroup categories, and that perceiving the stigmatized outgroup as included in a superordinate group would increase the emotional responses to the outgroup's unfair disadvantaged position. Consistently, the effect on reduced prejudice was mediated by feelings of injustice. However, there was no direct evidence that the effect depended on increased perceptions of belonging to a common group, since the authors did not test whether onegroup perceptions also acted as a mediator and, especially, as a pre-condition of feelings of injustice. In order to provide stronger confirmation for CIIM predictions, it is necessary to show that the effects of a threat external to ingroup and outgroup directed at both groups on outgroup attitudes are mediated by one-group perceptions. Banfield 


\section{NATURAL DISASTERS AND COMMON INGROUP IDENTITY}

and Dovidio (2013, Study 1) also investigated the relationship between common ingroup identity and external threat. The authors found that American-Whites induced to perceive a common identity with Blacks tended to recognize to a greater extent that Blacks are discriminated against on the job market. However, this effect was only present when an external threat was salient (i.e., when the US were presented as $17^{\text {th }}$ in the world for education), compared to when the threat was not salient.

\section{Majority and minority responses to the threat of a natural disaster}

In the previous paragraph we reviewed studies examining majority group members, showing that an external threat directed at both ingroup and outgroup reduces prejudice towards minority groups (Dovidio et al., 2004, Study 2) and that, once activated, a one-group perception stemming from an external threat improves attitudes towards minority members (Banfield \& Dovidio, 2013, Study 1). We sought to merge this evidence by demonstrating that an external threat direct at both ingroup and outgroup fosters the adoption of a common ingroup identity which, in turn, should have positive effects on outgroup attitudes and behavioural intentions. The suggested model is consistent with the CIIM (Gaertner \& Dovidio, 2000, 2012). Our aim is to explore whether the hypothesized processes might differ among majority and minority members. In particular, we acknowledge the possibility that disaster threat will influence dependent variables via one-group perceptions only among majority group members.

As noted by Hebl and Dovidio (2005; see also Demoulin, Leyens, \& Dovidio, 2009), majority and minority members enter intergroup interactions with different expectations and personal experiences, which may shape their subjective interpretations of social reality. Consistently, research has shown that majority and minority members 


\section{NATURAL DISASTERS AND COMMON INGROUP IDENTITY}

have different perspectives, which contribute to determine the course of intergroup relations (Hyers \& Swim, 1998; Shelton, Dovidio, Hebl, \& Richeson, 2009; Shelton, Richeson, \& Vorauer, 2006; Vorauer, 2006). Majority members are generally less inclined to pay attention to status differences and are more ready to adopt a one-group representation, compared with minority group members (Dovidio, Gaertner, \& Saguy, 2007, 2009; Leach, Snider, \& Iyer, 2002). The stronger attention placed by minorities on the differential status position compared to the advantaged group not only makes minority members more unlikely to see themselves as included in a superordinate group together with the majority group; attention to features defining respective group memberships by minority group members may reduce the impact of experiences meant to strengthen bonds between groups (Shelton \& Richeson, 2006; Shelton, Richeson, \& Salvatore, 2005). For instance, there is evidence showing that intergroup contact (a crucial antecedent of stronger one-group perceptions; Gaertner \& Dovidio, 2000) has weaker effects for minorities compared with majorities (Binder et al., 2009; Vezzali, Giovannini, \& Capozza, 2010; for a meta-analysis, see Tropp \& Pettigrew, 2005).

From the point of view of minority members, an external threat should act towards reducing perception of status differences, as both majority and minority members are potential victims, with no distinction between groups. However, in some situations, threat perceptions may be not equally shared between groups. For instance, in the aftermath of an earthquake such as that under investigation in the present study, the disadvantaged status position of minority group members, who are likely to be affected by the disaster more strongly than majority group members, may become more salient. 


\section{NATURAL DISASTERS AND COMMON INGROUP IDENTITY}

Consistently, Andrighetto, Vezzali, Bergamini, Nadi and Giovannini (2014) found, in the aftermath of the earthquake that struck Northern Italy in 2012 (that is, in the context where the present study was conducted) that tent cities provided by institutions after the disaster were proportionally inhabited more by immigrant (minority) than by Italian (majority) victims. This was likely due to the fact that Italians benefit from a wider social network and a better socio-economic situation compared with immigrants, so that the consequences of the earthquakes were less severe (or less evident) for the former than for the latter (see also Filippi, 2012). In other words, it was more likely for Italians than for immigrants to own anti-seismic houses, to have more economic resources to address damage to their houses, to be hosted at their relatives' or friends' houses in areas not struck (at least, not so severely) by the earthquake, thus avoiding living in tent cities.

Since minority members pursue the goal of avoiding being discriminated (Crocker, Major, \& Steele, 1998; Shelton, 2003) and of being treated fairly (Bergsieker, Shelton, \& Richeson, 2010; Shelton, Richeson, Salvatore, \& Trawalter, 2005), disaster threat is unlikely to lead to increased one-group perceptions for them. Indeed, higher perceived status differential (Stephan \& Stephan, 1985, 2000), coupled with less responsiveness to experiences bringing groups together (Tropp \& Pettigrew, 2005), may prevent the creation of a one-group identity.

However, we also predict that, among minority members, in line with the CIIM (Gaertner \& Dovidio, 2000), once activated, one-group perceptions should be associated with more positive outgroup attitudes and stronger intentions to meet and help outgroup members. In other words, although we do not expect a mediated effect of one-group perceptions in the relationship between disaster threat and outgroup attitudes, consistent 


\section{NATURAL DISASTERS AND COMMON INGROUP IDENTITY}

with previous research, we predict a positive association between one-group representation and outcome variables (Gonzalez \& Brown, 2006).

\section{The association between outgroup attitudes and outgroup behavioural intentions}

Although in our model we include outgroup attitudes and contact and helping behavioural intentions towards the outgroup as outcome variables, in the model we propose we do not test them at the same level. Our predictions go a step further, by sequentially linking group representations and outgroup attitudes to behavioural

intentions. Specifically, we predict that group representations (stemming, for the majority group, from perceived disaster threat) should influence outgroup attitudes which, in turn, should be positively associated with stronger intentions to meet and help outgroup members. This latter prediction is consistent with the theory of planned behaviour (TPB; Ajzen \& Fishbein, 1980, 2005; Fishben \& Ajzen, 1974), stating that attitudes work as antecedent of intentions. Our interest in testing behavioural intentions, in addition to outgroup attitudes, stems from that, according to TPB, behavioural intentions represent the most proximal predictor of actual behaviour (Ajzen, 1991; Godin \& Kok, 1996; Sheeran, 2002; Vallacher \& Wegner, 1987). If our hypotheses are correct, then our results would shed light on the processes which are likely to impact on actual behaviour aimed at meeting and helping outgroup children who are victims of the earthquake.

\section{The present research}

The percentage of immigrants in Modena, where the study was conducted, was $12.4 \%$, compared with the overall Italian situation at the end of 2012, where the percentage of immigrants was 7.3\% (National Institute of Statistics, 2013). Relations between Italians and immigrants in this context are generally conflictual. In particular, 


\section{NATURAL DISASTERS AND COMMON INGROUP IDENTITY}

Italians have been shown to hold negative attitudes towards immigrants (Giovannini \& Vezzali, 2012), even when relationships among adolescents (Vezzali et al., 2010) or young children (Vezzali, Giovannini, \& Capozza, 2012) are taken into consideration. In this multicultural context it is likely that a relevant event such as an earthquake affects relations between groups who experience contact on a daily basis.

Figure 1

We tested the four-level model presented in Figure 1. Perceived disaster threat was examined as the independent variable (first-level). Based on the literature reviewed above, among majority members, perceived disaster threat should be associated with group representations (second-level). Specifically, it should be positively associated with one-group perceptions and negatively associated with two-group perceptions. In contrast, the relation between perceived disaster threat and group representations should be nonsignificant among minority group members. In turn, consistent with the CIIM (Gaertner \& Dovidio, 2000, 2012), one-group and two-groups perceptions should act as mediators (positively and negatively, respectively) on positive outgroup attitudes (thirdlevel). Finally, outgroup attitudes should be predictive of behavioural intentions (fourthlevel) among both majority and minority members. Specifically, more positive outgroup attitudes should be associated with stronger intentions to meet and help outgroup members. However, we also acknowledge a residual direct, unmediated effect of group representations on behavioural intentions. Indeed, there is evidence that individuals are more likely to help and prefer having contact with ingroup (in our case, members of the victim group) rather than with outgroup members (Nier et al., 2001; Shook \& Fazio, 


\section{NATURAL DISASTERS AND COMMON INGROUP IDENTITY}

2008). Thus, feeling members of a same group (as opposed as perceiving ingroup and outgroup as distinct groups) should induce greater desire to meet and help members of the newly formed ingroup.

Identifying the path leading from perceived disaster threat to outgroup attitudes and, in turn, outgroup behavioural intentions, would have both theoretical and practical implications. Indeed, it would allow to understand the processes involved in improving intergroup relations in the aftermath of natural disasters and provide indications on how fostering more positive contact and helping behaviours among victims belonging to distinct groups.

\section{Method}

\section{Participants and Procedure}

Participants were 395 Italian (193 males, 202 females) and 122 immigrant (61 males, 61 females) elementary school children from five primary schools in the province of Modena. The distinction between Italian and immigrant participants was made on the basis of the schools' indications, taking into account the family background of children (i.e., whether children had immigrant parents). Most immigrants were from Asia (41.8\%), followed by immigrants from Africa (37.7\%), Eastern Europe (19.7\%) and Southern America (0.8\%). The mean age was 9 years 6 months (age range from 7 years 7 months to 12 years 9 months). Approximately six months after the two powerful earthquakes of May 2012, participants were administered a questionnaire during classes, presented as research on the consequences of the earthquake. Prior to conducting the study, we secured the consent of the children's parents, teachers and school heads.

\section{Questionnaire}




\section{NATURAL DISASTERS AND COMMON INGROUP IDENTITY}

All items were presented in Italian; for ease of presentation, below we present the English translation of the original items.

Perceived disaster threat. We used three items: "Were you frightened by the earthquake?"; "Does thinking of the earthquake make you feel sick?"; "Are you afraid that the earthquake might strike again?". The 4-step response scale ranged from 1 (not at all) to 4 (very much). Items were averaged (alphas $=.70$ and .73 for Italians and immigrants, respectively), with higher scores reflecting greater perceived disaster threat.

Group representations. In line with research on the CIIM, two-groups and onegroup perceptions were assessed with two single-item measures (e.g., Gaertner et al., 1989). Specifically, participants were asked: "Do Italian and immigrant children victims of the earthquake" "belong to different groups?" (two-groups representation) or "belong to a single group, the group of children?" (one-group representation). For both items a 4-step scale was used ( 1 = absolutely not; 4 = absolutely yes $)$.

Outgroup attitudes. A feeling thermometer was used to assess outgroup attitudes, one for Italian and one for immigrant child victims. Participants were given the following instructions: "This scale measures how you feel towards social groups; numbers go from 0 to 10 degrees, like in a thermometer. The higher the number, the more positive you feel towards the group." The response scale was anchored by 0 (I don't like them at all) and 10 (I like them very much); 5 was the neutral point (so so). Participants were then asked to evaluate (among some filler items) the outgroup (Italians, for immigrants; immigrants, for Italians), by using the scale provided.

Contact behavioural intentions. Three items were used, adapted from Cameron and Rutland (2006) and from Vezzali, Capozza, Stathi, and Giovannini (2012): "If you meet at the park an unknown immigrant [Italian] child who is victim of the earthquake 


\section{NATURAL DISASTERS AND COMMON INGROUP IDENTITY}

as you are," "Would you like to know him/her?"; "Would like to play with him/her?"; "Would like to go and have an ice-cream with him/her?". The 4-step response scale ranged from 1 (absolutely not) to 4 (absolutely yes). Items were averaged (alpha $=.83$ for Italians and .80 for immigrants): higher scores indicate more positive intentions to have contact with a child outgroup victim.

Helping behavioural intentions. We used three items, adapted from Vezzali et al. (2014): "If, when you are at school, an immigrant [Italian] child who is victim of the earthquake as you are has problems in writing a text, do you help him/her?"; "If, when you are at school, an immigrant [Italian] child who is victim of the earthquake as you are has problems in doing mathematics, do you help him/her?"; "If, when you are at school, an immigrant [Italian] child who is victim of the earthquake as you are has lost a book, do you help him/her to find it?". A 4-step response scale was used ( 1 = absolutely not; 4 = absolutely yes). A single index of helping behavioural intentions was computed by averaging the three items (alphas $=.81$ and .82 for Italians and immigrants, respectively), with higher scores reflecting stronger intentions to help child outgroup victims.

\section{Results}

\section{Preliminary analyses}

Descriptive statistics and correlations among variables are presented in Table 1. As can be noted, perceived disaster threat was moderate and slightly stronger for Italians than for immigrants, $t(515)=1.96, p=.05$. Both groups' perceptions of belonging to a common group were higher than perceptions of belonging to different groups: $t(394)=14.87, p<.001$, for Italians, and $t(121)=6.22, p<.001$, for immigrants. Not surprisingly, Italians (high-status group) evaluated the outgroup less 


\section{NATURAL DISASTERS AND COMMON INGROUP IDENTITY}

positively than immigrants (low-status group), $t(515)=3.19, p<.01$. Although contact intentions were moderately high for both groups, they were higher for immigrants than for Italians, $t(515)=3.75, p<.001$. Finally, helping intentions were generally high among both groups.

\section{Table 1}

\section{Path model}

In order to test the hypothesis that perceived disaster threat would have differential effects for the Italian and for the immigrant sample, we tested whether participants' group of belonging (Italian vs. immigrant) moderated the relationships in the proposed model by using multiple group analysis. Before conducting this analysis, we tested the hypothesized model (Figure 1) separately for Italians and immigrants to verify whether it showed an adequate fit. Path analysis with observed variables was used (LISREL 8.7; Jöreskog \& Sörbom, 2004). The goodness-of-fit of the model was assessed by using the chi-square test, the standardized root-mean-square residual (SRMR), the root-mean-square error of approximation (RMSEA), and the comparative fit index (CFI). An acceptable fit to the data is indicated by a $\chi^{2} / d f$ ratio of less than 3 , a SRMR equal or less than .08, a RMSEA equal or less than .06, and a CFI equal or greater than .95 (Hu \& Bentler, 1999). One-group and two-groups representations were allowed to correlate, since they were significantly correlated. For the same reason, the correlation between contact and helping intentions was allowed (see Table 1). 


\section{NATURAL DISASTERS AND COMMON INGROUP IDENTITY}

Although the path model for the immigrant sample showed an adequate fit, $\chi^{2}(3)$ $=2.69, p=.44 ; \chi^{2} / d f=0.90 ; \mathrm{SRMR}=.030 ; \mathrm{RMSEA} \cong .00 \mathrm{CFI}=1.00$, the model fit for the Italian sample was poor: $\chi^{2}(3)=13.20, p=.004 ; \chi^{2} / d f=4.40 ;$ SRMR $=.040$; RMSEA $=.09 ; \mathrm{CFI}=.98$. On the basis of bivariate correlations showed in Table 1 and modification indices of the model ( $\mathrm{MI}=12.95$ for the Italian sample), the path from perceived disaster threat to outgroup attitudes was added for both groups. This model fitted the data well both for Italians, $\chi^{2}(2)=0.031, p=.98 ; \chi^{2} / d f=0.02 ; \mathrm{SRMR}=.002$; $\mathrm{RMSEA} \cong .00 ; \mathrm{CFI}=1.00$, and immigrants, $\chi^{2}(2)=1.59, p=.45 ; \chi^{2} / d f=0.80 ; \mathrm{SRMR}=$ $.025 ; \mathrm{RMSEA} \cong .00 ; \mathrm{CFI}=1.00$.

Next, we ran multiple group analysis. We first tested a model in which path coefficients were allowed to be freely estimated across samples, and then compared this model with another model in which path coefficients were constrained to be equal. We used the chi-square difference test (Satorra \& Bentler, 1999) to compare these nested models. The fit of the unconstrained model was good: $\chi^{2}(4)=1.62, p=.80 ; \chi^{2} / d f=$ $0.40 ; \mathrm{SRMR}=.025 ; \mathrm{RMSEA} \cong .00 ; \mathrm{CFI}=1.00$. Constraining the path coefficients to be equal across samples resulted in a marginally significant drop of model fit: $\Delta \chi^{2}(11)=$ $19.46, p=.053$. Specifically, the path from perceived threat disaster to one-group perceptions, $\Delta \chi^{2}(1)=4.50, p=.034$, and the path from perceived threat to outgroup attitudes, $\Delta \chi^{2}(1)=7.04, p=.008$, were significantly different across the two samples. In line with our hypothesis, the two paths were significant for Italians, $\beta=.16, p<.01$, and $\beta=.17, p<.001$, respectively, but not for immigrants, $\beta=-.06, n s$, and $\beta=-.09, n s$, respectively. Likewise, the path from outgroup attitudes to contact intentions was different across the two samples, $\Delta \chi^{2}(1)=4.01, p=.045$. Outgroup attitudes were significantly associated with contact intentions among Italians, $\beta=.22, p<.001$, but not 


\section{NATURAL DISASTERS AND COMMON INGROUP IDENTITY}

among immigrants, $\beta=.05, n s$. These results support the hypothesis of different effects of perceived disaster threat across the two groups and justify the hypothesized model being examined separately for Italians and immigrants.

In line with expectations, in the model for Italian participants (Figure 2), perceived disaster threat was associated with reduced two-groups representation and with increased perceptions of belonging to a common group. Moreover, one-group perceptions were associated with more positive outgroup attitudes, whereas two-groups perceptions were negatively related to outgroup attitudes. The latter was in turn associated with more positive contact and helping intentions. Finally, the residual direct path from perceived disaster threat to outgroup attitudes was significant, as well as the paths from one-group representation to contact and helping intentions.

Figure 2

Indirect effects of perceived disaster threat via the proposed mediators were tested using the bootstrapping method (Preacher \& Hayes, 2008; for three-path indirect effects, see Taylor, MacKinnon, \& Tein, 2008) with 2,000 bootstrap samples. An indirect effect is considered significant if the bootstrap confidence interval does not include zero. Results are shown in Table 2 . As can be seen, fully supporting our hypotheses, higher levels of perceived disaster threat were positively associated with stronger intentions to meet and help outgroup members via increased one-group perceptions (and decreased two-group perceptions) and improved outgroup attitudes. Moreover, consistent with predictions based on TPB (Fishben \& Ajzen, 1974), the 


\section{NATURAL DISASTERS AND COMMON INGROUP IDENTITY}

indirect effects of one-group and two-groups representations on contact and helping intentions via outgroup attitudes were significant.

Table 2, Figure 3

The path model for the immigrant sample is shown in Figure 3. In line with our hypothesis, perceived disaster threat was unrelated to one-group and two-groups representations. Partially in line with predictions and consistent with the CIIM (Gaertner \& Dovidio, 2000), perceiving ingroup and outgroup as a single group had positive effects on outgroup attitudes (marginal effect), contact and helping intentions.

Inspection of indirect effects with bootstrapping procedures (Table 2) revealed that, unsurprisingly, the three-path indirect effects from perceived disaster threat to outgroup behavioural intentions were nonsignificant. Moreover, contrary to predictions based on TPB (Fishben \& Ajzen, 1974), the indirect effects of one-group representation on contact and helping intentions via outgroup attitudes were nonsignificant. ${ }^{1,2}$

\section{Alternative models}

We tested three alternative models. Fit indices of the alternative models for both samples are summarized in Table 3.

Table 3

To compare these competing models, we used Akaike's (1987) information criterion (AIC) as an additional index. The first alternative model (Model 2) tested contact intentions as predictor of outgroup attitudes and helping intentions via group 


\section{NATURAL DISASTERS AND COMMON INGROUP IDENTITY}

representations and perceived disaster threat. The second alternative model (Model 3), tested helping intentions as predictor of perceived disaster threat and outgroup attitudes via contact intentions and group representations. In the third alternative model (Model 4), contact and helping intentions were tested as predictors of group representations via perceived disaster threat and outgroup attitudes. As can be seen in Table 3, for the Italian sample, these alternative models did not fit the data as well as the original model (Model 1). In addition, the original model showed the lowest AIC value, thus suggesting that it fits the data better than the other tested models. For the immigrant sample, Model 4 yielded a poorer model fit than the original model, whereas the fit of Models 2 and 3 was similar to that of the original model. However, the examination of model parameters showed that only two paths were significant for both Models 2 and 3 . Specifically, in Model 2, the paths from contact intentions to one-group perceptions and helping intentions were significant; in Model 3, the path from helping intentions to contact intentions and the path from contact intentions to one-group perceptions were significant. All the other paths did not approach significance. Therefore, although Models 2 and 3 fit the data as well as the hypothesized model, they do not seem to provide a better explanation of the data compared with the hypothesized model.

\section{Discussion}

We conducted a field study to test the CIIM (Gaertner \& Dovidio, 2000, 2012) in the aftermath of a natural disaster. We focused on children, as they are especially vulnerable to the consequences of natural disasters and it is thus important to identify protective factors, such as positive intergroup relations within multicultural communities. One important aspect of the study is to have considered simultaneously the perspective of both majority and minority members, which allowed us to highlight 


\section{NATURAL DISASTERS AND COMMON INGROUP IDENTITY}

different ways of responding to the threat following a natural disaster. In particular, perceived external threat represented by the disaster induced Italian (majority) children to feel like a single group with immigrants (minority). In turn, increased one-group perceptions were associated with a greater desire to meet and help outgroup victims directly and (for Italians) indirectly via more positive outgroup attitudes.

On a theoretical level, our findings complement and extend previous results, by providing for the first time support for the CIIM (Gaertner \& Dovidio, 2000) as a prejudice-reduction strategy in the aftermath of a natural disaster. First, results showed that, among majority group members, an external threat influenced outgroup attitudes and behavioural intentions by transforming the representation from two-groups to onegroup. Second, once activated, one-group representation influenced outgroup attitudes and behavioural intentions among both majority and minority members. The fact that effects of group representations were weaker (or absent, in the case of two-groups representation) among immigrants may indicate that minority members base their attitudes to a lesser extent on social categorizations as group victims. However, we suspect that weaker results may also depend on the smaller sample size (as the direction and size of correlations seem to suggest).

One possible explanation for the finding that effects were stronger for one-group rather than for two-group perceptions may concern the fact that participants base their positive outgroup attitudes and intentions more on perceptions of similarity (i.e., onegroup) rather than dissimilarity (i.e., two-groups) from outgroup. This argument is consistent with findings showing that ingroup members are evaluated more positively and helped to a greater extent than outgroup members (Tajfel \& Turner, 1979; van Leeuwen \& Täuber, 2011). On the other hand, the fact that ingroup-outgroup 


\section{NATURAL DISASTERS AND COMMON INGROUP IDENTITY}

distinctions do not necessarily lead to more negative outgroup attitudes (cf. Brewer, 1999) helps to explain why the two-groups representation was unrelated to dependent variables (all focused on outgroup attitudes). To this regard, it should be noted that onegroup and two-group perceptions were only moderately negatively correlated, suggesting that adopting an inclusive representation is not exactly the opposite of rejecting a two-groups representation.

Finally, our findings (in particular, those of the majority group) support TPB (Fishben \& Ajzen, 1974), demonstrating that attitudes are a key factor driving behavioural intentions. The fact that one-group perceptions also had direct effects on behavioural intentions is not surprising: evidence shows that individuals are more likely to help and prefer having contact with ingroup (in our case, members of the victim group) rather than with outgroup members (Nier et al., 2001; Shook \& Fazio, 2008).

Of particular note, in line with expectations, effects of perceived disaster threat were only present among majority members. Generally, minority members are more likely than majority members to pay attention to status differences, thus reducing the impact of experiences which have the potential to improve intergroup relations, such as intergroup contact (Tropp \& Pettigrew, 2005). Possibly, the consequences of the earthquake (which affected more the immigrant than the Italian group; Andrighetto et al., 2014) strengthened this tendency, by drawing immigrants' attention on status differences, thereby preventing beneficial effects of the external threat.

It is interesting to note that perceived threat was slightly higher for Italians than for immigrants. This may be due to the fact that Italians, because of their generally higher socioeconomic situation as the majority group, live in better conditions and can thus be more disconcerted by an emergency situation threatening their lifestyle. 


\section{NATURAL DISASTERS AND COMMON INGROUP IDENTITY}

However, this is not in contrast with our findings, because perceiving threat to a higher degree does not imply that the disaster increased perceived status differential; on the contrary, it may have highlighted to a greater extent the danger of the situation, contributing to perceive the threat as shared between groups and increasing one-group perceptions among majority group members.

We note that the present results cannot be immediately generalized to threats in general. As argued above, perceived disaster threat is likely to have emphasized status differences among minority members. In other words, threat was unlikely to be equally shared between majority and minority group members. Other types of threat not involving differential consequences based on group of belonging (i.e., threats equally shared between groups) may act towards reducing perception of status differences, thus potentially enhancing one-group perceptions among minority group members. It is clearly possible that natural disasters in other situations produce a shared threat between groups. Thus, we argue that what is important for understanding the consequences of threats external to ingroup and outgroup on intergroup relations is whether or not these threats are equally shared between majority and minority groups. The distinction between shared and unshared threats departs from more classical distinctions between types of threats (e.g., realistic vs. symbolic; Stephan \& Stephan, 2000) and highlights the importance of considering the specific context where a threat is salient. Future studies may help to clarify the role played by different types of threats (shared vs. unshared) in influencing group representations and outgroup attitudes.

It is also worth noting that these results may be specific to children. Adults may have a more complex picture of the situation and be motivated by strategic aims. For instance, in the aftermath of a natural disaster, majority members may feel a common 


\section{NATURAL DISASTERS AND COMMON INGROUP IDENTITY}

ingroup identity as aversive (Dach-Gruschow \& Hong, 2006) and be threatened by the minority group, being afraid that minority members will spoil resources allocated by institutions to help recovering from the disaster. On the other hand, the minority group may be induced to feel like a single group with the aim of being assimilated to the majority, thus benefitting of aids allocated to disaster victims (Andrighetto et al., 2014).

Previous research has identified various factors associated with helping following a disaster (e.g., Marjanovic, Struthers, \& Greenglass, 2012; Zagefka, Noor, Brown, Hopthrow, \& Randsley de Moura, 2012; Zagefka, Noor, Brown, Randsley de Moura, \& Hopthrow, 2011), such as knowing more about an area where the disaster took place (Zagefka, Noor, \& Brown, 2013). Our study adds to this research by evaluating conditions and processes involved in fostering intergroup helping. Moreover, departing from most of existent literature (e.g., Sun, Zagefka, \& Goodwin, 2013), we examined effects among victims, who may especially need to support each other independently from race, in order to face disaster consequences more effectively.

We note that our measure of helping, coupled with the contact intention measure, tapped behaviours of mutual assistance and friendship that signal social support and peer acceptance, and did not concern behaviours directly related to the earthquake. The idea is that children should return to normal life, and apparently unimportant everyday acts of helping between victims may be relevant to regain normality. These types of behaviours may be especially important for children, as social support from outside the family, such as that from peers, has been shown to be a crucial factor in recovering from the stressful experience of a natural disaster (e.g., Cadamuro et al., in press; Pina et al., 2008). These intentions were strongly related to the experience of the earthquake, as we specifically referred to intentions towards outgroup 


\section{NATURAL DISASTERS AND COMMON INGROUP IDENTITY}

victims. However these intentions may also generalize outside the boundaries of the victim group to the whole outgroup category.

We acknowledge some limitations. First, data are correlational. Second, since immigrant children may identify with their ethnic group, we have no evidence that they would consider the general immigrant category as their ingroup; future studies should test hypotheses by considering immigrant children's specific ethnic group as the ingroup category. Concerning measures, outgroup attitudes were measured with a single item, and other measures had a 4-step scale without the midpoint; future studies should consider multi-item measures for attitudes and include the midpoint in the response scale. Also, we did not include items on intergroup contact, which has been shown to have a major role in influencing group representations (Gaertner \& Dovidio, 2000). We also omitted including items on socio-economic state, which would have been useful in providing a more direct test as to why effects of perceived disaster threat are only present among majority members. In addition, we did not include a measure of wellbeing, which could clarify whether children's well-being is associated with a superordinate identity. Future studies may address this fascinating possibility. A further point is that the proposed model is nearly fully saturated; we encourage future studies to test whether a more parsimonious account of the hypothesized processes is possible. Finally, for the immigrant sample, two alternative models fit the data as well as the proposed model. However, they reveal few significant paths, thus suggesting that they do not provide a better explanation for the data compared with our hypothesized model.

In conclusion, threat of natural disasters and one-group perceptions may have deep effects on intergroup relations, acting in the sense of strengthening community ties. These results may be of capital importance to practitioners, by indicating possible 
ways to capitalize on the effects of perceived disaster threat so as to cope more effectively at a community level with detrimental consequences of natural disasters. 


\section{NATURAL DISASTERS AND COMMON INGROUP IDENTITY}

\section{Footnotes}

1. We also tested a model in which dual identity (Gaertner \& Dovidio, 2000) was included as first-level mediator instead of one-group and two-groups representations. Dual identity refers to the simultaneous salience of both a superordinate identity including ingroup and outgroup and of original ingroup and outgroup categories. In this study, dual identity was computed as the product of one-group and two-groups representations (see, e.g., Vezzali, Capozza, Mari, \& Hichy, 2007). The model including dual identity showed an adequate fit both for the Italian and the immigrant sample. However, for both groups, the dual identity score was not significantly associated with any of the variables included in the model.

2. For both samples, including age, sex (males $=-1$, females $=1$ ), and school of belonging (coded using four dummy variables) as covariates in the path model (i.e., regressing all endogenous variables on these three covariates) did not affect the expected relationships between variables. Given the high age range, we also tested whether age moderated the hypothesized relationships by using hierarchical regression. Group (Italians $=1$, immigrants $=-1$ ) was entered in each regression model as the predictor. First, we tested perceived disaster threat, group, age (Step 1), the two-way (Step 2) and the three-way (Step 3) interactions as predictors of each group representation. A significant three-way interaction was found when one-group was the dependent variable, $\beta=-.10, p<.05$. Decomposition of the interaction showed that, for immigrants, perceived disaster threat was associated with higher perceptions of belonging to a common group among younger, $b=-.21, S E=.10, t=2.18, p<.05$, but not among older participants, $b=.03, S E=.10, t<1$. Next, we tested a similar model 


\section{NATURAL DISASTERS AND COMMON INGROUP IDENTITY}

including outgroup attitudes as the dependent variable; in this model, group representations and their interactions with group and age were added as additional predictors. No significant interaction emerged. Finally, two identical regression models were tested separately for contact intentions and helping intentions; in these models, we included outgroup attitudes and the interactions of this variable with group and age as further predictors. In the model including contact intentions as the outcome variable, a significant three-way interaction one-group representation $\times$ group $\times$ age was found, $\beta=$ $.10, p<.05$. Simple slope analysis showed that, for both groups, the residual effect of one-group representation on contact intentions was significant among younger participants (for Italians: $b=.11, S E=.04, t=2.81, p<.01$; for immigrants: $b=.21, S E$ $=.07, t=2.96, p<.01$ ), while it was nonsignificant among older immigrant participants $(b=-.06, S E=.08, t<1)$ and marginally significant among older Italian participants $(b$ $=.13, S E=.07, t=1.92, p<.06)$.

These hierarchical regression analyses were replicated by replacing age with gender $($ males $=-1$, females $=1$ ). In the regression model including helping intentions as the outcome variable, a significant interaction one-group $\times$ gender was found, $\beta=-$ $.08, p<.05$. For both groups, the residual effect of one-group perceptions was significant among males, $b=.12, S E=.04, t=3.11, p<.05$, but not among females, $b=$ $-.004, S E=.04, t<1$. Moreover, the interaction perceived disaster threat $\times$ gender was marginally significant, $\beta=-.06, p=.062$. For both groups, the residual effect of perceived disaster threat was significant among males, $b=.10, S E=.04, t=2.34, p<$ .01 , but not among females, $b=-.007, S E=.04, t<1$. No other significant interaction effects were found. 


\section{NATURAL DISASTERS AND COMMON INGROUP IDENTITY}

\section{References}

Ajzen, I. (1991). The theory of planned behaviour. Organizational Behaviour and Human Decision Processes, 50, 179-211. doi: 10.1080/01490409109513137

Ajzen, I., \& Fishbein, M. (1980). Understanding attitudes and predicting social behaviour. Englewood Cliffs, NJ: Prentice Hall.

Ajzen, I., \& Fishbein, M. (2005). The influence of attitudes on behaviour. In D.

Albarracion, B. T. Johnson, \& M. P. Zanna (Eds.), The handbook of attitudes (pp. 173221). Mahawah, NJ: Erlbaum.

Akaike, H. (1987). Factor analysis and AIC. Psychometrika, 3, 317-332. doi: 10.1007/BF02294359

Andrighetto, L., Vezzali, L., Bergamini, G., Nadi, C., \& Giovannini, D. (2014). Inside the earthquake: Disaster exposure and helping intentions among Italian and immigrant victims of 2012 Italian earthquake. Under review.

Banfield, J. C., \& Dovidio, J. F. (2013). Whites' perceptions of discrimination against Blacks: The influence of common identity. Journal of Experimental Social Psychology, 49, 833-841. doi: 10.1016/j.jesp.2013.04.008

Bergsieker, H., Shelton, J, N., \& Richeson, J. A. (2010). To be liked or respected: Whites' and minorities' divergent goals during interracial interactions. Journal of Personality and Social Psychology, 99, 248-264. doi: 10.1037/a0018474

Binder, J., Zagefka, H., Brown, R., Funke, F., Kessler, T., \& Mummendey, A. (2009). Does contact reduce prejudice or does prejudice reduce contact? A longitudinal test of the contact hypothesis among majority and minority groups in three European countries. Journal of Personality and Social Psychology, 96, 843-856. doi: 10.1037/a0013470 


\section{NATURAL DISASTERS AND COMMON INGROUP IDENTITY}

Brewer, M. B. (1999). The psychology of prejudice: Ingroup love or outgroup hate? Journal of Social Issues, 55, 429-444. doi: 10.1111/0022-4537.00126

Cadamuro, A., \& Versari, A. (2012). Children's Post Traumatic Stress Disorder and psychological functioning in the aftermath of the earthquakes which struck Emilia Romagna in 2012. Unpublished manuscript.

Cadamuro, A., Versari, A., Vezzali, L., Giovannini, D., \& Trifiletti, E. (in press). Cognitive performance in the aftermath of a natural disaster; The role of coping strategies, theory of mind and peer social support. Child and Youth Care Forum. doi: $10.1007 / \mathrm{s} 10566-014-9272-\mathrm{z}$

Cameron, L., \& Rutland, A. (2006). Extended contact through story reading in school: Reducing children's prejudice toward the disabled. Journal of Social Issues, 62, 469488. doi: 10.1111/j.1540-4560.2006.00469.x

Capozza, D., Trifiletti, E., Vezzali, L., \& Favara, I. (2013). Can contact improve humanity attributions? International Journal of Psychology, 48, 527-541. doi: $10.1080 / 00207594.2012 .688132$

Capozza, D., Vezzali, L., Trifiletti, E., Falvo, R., \& Favara, I. (2010). Improving intergroup relationships within and outside the contact situation: The role of common ingroup identity and emotions of anxiety and empathy. Testing, Psychometrics, Methodology in Applied Psychology, 17, 17-36.

Crocker, J., Major, B., \& Steele, C. M. (1998). Social stigma. In D. T. Gilbert, S. T. Fiske, \& G. Lindzey (Eds.), Handbook of social psychology (4th ed., pp. 504-533). Boston, MA: McGraw-Hill. 


\section{NATURAL DISASTERS AND COMMON INGROUP IDENTITY}

Cuddy, A., Rock, M., \& Norton, M. (2007). Aid in the aftermath of hurricane Katrina: Inferences of secondary emotions and intergroup helping. Group Processes and Intergroup Relations, 10, 107-118. doi: 10.1177/1368430207071344

Dach-Gruschow, K., \& Hong, Y. (2006). The racial divide in response to the aftermath of Katrina: A boundary condition for common ingroup identity model. Analyses of Social Issues and Public Policy, 6, 125-141. doi: 10.1111/j.1530-2415.2006.00110.x

Demoulin, S., Leyens, J. Ph., \& Dovidio, J. F. (2009). Intergroup misunderstandings: Interactions and divergences in realities, goals, and strategies. In S. Demoulin, J. Ph. Leyens, \& J. F. Dovidio (Eds.), Intergroup misunderstandings: Impact of divergent social realities (pp. 1-19). New York, NY: Psychology Press.

Dovidio, J., Gaertner, S. L., \& Saguy, T. (2007). Another view of "we": Majority and minority group perspectives on a common ingroup identity. In W. Stroebe \& M. Hewstone (Eds.), European review of social psychology (Vol. 18, pp. 296-330). Chichester, UK: Wiley. doi: 10.1080/10463280701726132

Dovidio, J., Gaertner, S. L., \& Saguy, T. (2009). Commonality and the complexity of "we": Social attitudes and social change. Personality and Social Psychology Review, 13, 3-20. doi: 10.1177/1088868308326751

Dovidio, J. F., Gaertner, S. L., Validzic, A., Matoka, A., Johnson, B., \& Frazier, S. (1997). Extending the benefits of recategorization: Evaluations, self-disclosure, and helping. Journal of Experimental Social Psychology, 33, 401-420. doi: 10.1006/jesp.1997.1327

Dovidio, J. F., ten Vergert, M., Stewart, T. L., Gaertner, S. L., Johnson, J. D., Esses, V. M...\& Pearson, A. R. (2004). Perspective and prejudice: Antecedents and mediating mechanisms. Personality and Social Psychology Bulletin, 30, 1537-1549. doi: $10.1177 / 0146167204271177$ 


\section{NATURAL DISASTERS AND COMMON INGROUP IDENTITY}

Eccleston, C. P., Kaiser, C. R., \& Kraynak, L. R. (2010). Shifts in justice beliefs induced by hurricane Katrina: The impact of claims of racism. Group Processes and Intergroup Relations, 13, 571-584. doi: 10.1177/1368430210362436

Filippi, S. (2012). Terremoto, gli immigrati conquistano le tendopoli. Gli italiani si arrangiano [Earthquake, immigrants conquer tent cities. Italians manage]. Retrieved on

$25^{\text {th }}$ April 2014 from http://www.ilgiornale.it/news/cronache/terremoto-immigraticonquistano-tendopoli-italiani-si.html

Fishbein, M., \& Ajzen, I. (1974). Attitudes towards objects as predictors of single and multiple behavioural criteria. Psychological Review, 8, 59-74. doi: 10.1037/h0035872

Furr, J. M., Corner, J. S., Edmunds, J. M., \& Kendall, P. C. (2010). Disasters and youth: A meta-analytic examination of posttraumatic stress. Journal of Consulting and Clinical Psychology, 78, 765-780. doi: 10.1037/a0021482

Gaertner, S. L., \& Dovidio, J. F. (2000). Reducing intergroup bias: The common ingroup identity model. Philadelphia, PA: Psychology Press.

Gaertner, S. L., \& Dovidio, J. F. (2012). The common ingroup identity model. In P. A. M. Van Lange, A. W. Kruglanski, \& E. T. Higgins (Eds.), Handbook of theories of social psychology (Vol. 2, pp. 439-457). Thousand Oaks, CA: Sage.

Gaertner, S., Mann, J., Murrell, A., \& Dovidio, J. F. (1989). Reducing intergroup bias: The benefits of recategorization. Journal of Personality and Social Psychology, 57, 239-249. doi: 10.1037/0022-3514.57.2.239

Gaertner, S. L., Rust, Dovidio, J. F., Bachman, B. A., \& Anastasio, P. A. (1994). The contact hypothesis: The role of a common ingroup identity on reducing intergroup bias. Small Group Research, 25, 224-249. doi: 10.1177/1046496494252005 


\section{NATURAL DISASTERS AND COMMON INGROUP IDENTITY}

Giovannini, D., \& Vezzali, L. (Eds.) (2012). Lavorare insieme. Imprese cooperative, climi lavorativi e immigrazione [Working together. Cooperative enterprises, working climates and immigration]. Milano, Italy: Edizioni Guerini e associati.

Godin, G., \& Kok, G. (1996). The theory of planned behaviour: A review of its applications to health related behaviours. American Journal of Health Promotion, 11, 87-98. doi: 10.4278/0890-1171-11.2.87

Gonzalez, R., \& Brown, R. (2003). Generalization of positive attitude as a function of subgroup and superordinate group identifications in intergroup contact. European Journal of Social Psychology, 33, 195-214. doi: 10.1002/ejsp.140

Gonzalez, R., \& Brown, R. (2006). Dual identities in intergroup contact: Group status and size moderate the generalization of positive attitude change. Journal of Experimental Social Psychology, 42, 753-767. doi: 10.1016/j.jesp.2005.11.008

Guerra, R., Rebelo, M., Monteiro, M. B., \& Gaertner, S. L. (2013). Translating recategorization strategies into an antibias educational intervention. Journal of Applied Social Psychology, 43, 14-23. doi: 10.1111/j.1559-1816.2012.00976.x

Guerra, R., Rebelo, M., Monteiro, M. B., Riek, B. M., Mania, E. W., Gaertner, S. L., \& Dovidio, J. F. (2010). How should intergroup contact be structured to reduce bias among majority and minority group children? Group Processes and Intergroup Relations, 13, 445-460. doi: 10.1177/1368430209355651

Gurwitch, R. H., Kees, M., \& Becker, S. M. (2002). In the face of tragedy: Placing children's reactions to trauma in a new context. Cognitive and Behavioral Practice, 9, 286-295. doi: 10.1016/S1077-7229(02)80022-0 


\section{NATURAL DISASTERS AND COMMON INGROUP IDENTITY}

Hall, N. R., Crisp, R. J., \& Suen, M. (2009). Reducing implicit prejudice by blurring intergroup boundaries. Basic and Applied Social Psychology, 31, 244-254. doi: $10.1080 / 01973530903058474$

Hebl, M. R., \& Dovidio, J. F. (2005). Promoting the "social" in the examination of social stigmas. Personality and Social Psychology Review, 9, 156-182. doi: 10.1207/s15327957pspr0902_4

Hu, L., \& Bentler, P. M. (1999). Cutoff criteria for fit indexes in covariance structure analysis: Conventional criteria versus new alternatives. Structural Equation Modeling, 6, 1-55. doi: 10.1080/10705519909540118

Hyers, L. L., \& Swim, J. K. (1998). A comparison of the experiences of dominant and minority group members during an intergroup encounter. Group Processes and Intergroup Relations, 1, 143-163. doi: 10.1177/1368430298012003

Jöreskog, K. G., \& Sörbom, D. (2004). LISREL 8.7 for Windows [Computer Software]. Lincolnwood, IL: Scientific Software International, Inc.

Kaiser, C. R., Eccleston, C. P., \& Hagiwara, N. (2008). Post-Hurricane Katrina racialized explanations as a system threat: Implications for Whites' and Blacks' racial attitudes. Social Justice Research, 21, 192-203. doi: 10.1007/s11211-008-0065-0

Kar, N., \& Bastia, B. K. (2006). Post Traumatic Stress Disorder, depression and generalised anxiety disorder in adolescent after a natural disaster: A study of comorbidity. Clinical Practice and Epidemiology in Mental Health, 2, 17. doi: $10.1186 / 1745-0179-2-17$

La Greca, A. M., Silverman, W. K., Lai, B., \& Jaccard, J. (2010). Hurricane-related exposure experiences and stressors, other life events, and social support: Concurrent and 


\section{NATURAL DISASTERS AND COMMON INGROUP IDENTITY}

prospective impact on children's persistent posttraumatic stress symptoms. Journal of Consulting and Clinical Psychology, 78, 794-805. doi: 10.1037/a0020775

Leach, C. W., Snider, N., \& Iyer, A. (2002). Poisoning the consciences of the fortunate: The experience of relative advantage and support for social equality. In I. Walker \& H. J. Smith (Eds.), Relative deprivation: Specification, development, and integration (pp. 136-163). Cambridge, UK: Cambridge University Press.

Levin, S., Sinclair, S., Sidanius, J., \& Van Laar, C. (2009). Ethnic and university identities across the college years: A common in-group identity perspective. Journal of Social Issues, 65, 287-306. doi: 10.1111/j.1540-4560.2009.01601.x

Marjanovic, Z., Struthers, C. W., \& Greenglass, E. R. (2012). Who helps natural-disaster victims? Assessment of trait and situational predictors. Analyses of Social Issues and Public Policy, 12, 245-267. doi: 10.1111/j.1530-2415.2011.01262.x

National Institute of Statistic (2013). Demography in numbers. Retrieved $9^{\text {th }}$ september 2013 from http://demo.istat.it

Nier, J. A., Gaertner, S. L., Dovidio, J. F., Banker, B. S., Ward, C. M., \& Rust, M. C. (2001). Changing interracial evaluations and behavior: The effects of a common ingroup identity. Group Processes and Intergroup Relations, 4, 299-316. doi: $10.1177 / 1368430201004004001$

Pina, A. A., Villalta, I. K., Ortiz, C. D., Gottschall, A. C., Costa, N. M., \& Weems, C. F. (2008). Social support, discrimination, and coping as predictors of posttraumatic stress reactions in youth survivors of Hurricane Katrina. Journal of Clinical Child an Adolescent Psychology, 37, 564-574. doi: 10.1080/15374410802148228 


\section{NATURAL DISASTERS AND COMMON INGROUP IDENTITY}

Preacher, K. J., \& Hayes, A. F. (2008). Asymptotic and resampling strategies for assessing and comparing indirect effects in multiple mediator models. Behavior Research Methods, 40, 879-881. doi: 10.3758/BRM.40.3.879

Riek, B. M., Mania, E. W., Gaertner, S. L., McDonald, S. A., \& Lamoreaux, M. J. (2010). Does a common identity reduce intergroup threat? Group Processes and Intergroup Relations, 13, 403-423. doi: 10.1177/1368430209346701

Satorra, S., \& Bentler, P.M. (1999). A scaled difference chi-square test statistic for moment structure analysis. Unpublished technical report, Universitat Pompeu Fabra, Barcelona, Spain.

Schofield, J. W., Hausmann, L. R. M., Ye, F., \& Woods, R. L. (2010). Intergroup friendships on campus: Predicting close and casual friendships between White and African american first-year college students. Group Processes and Intergroup Relations, 13, 585-602. doi: 10.1177/1368430210362437

Sheeran, P. (2002). Intention-behavior relations: A conceptual and empirical review. In W. Stroebe \& M. Hewstone (Eds.), European review of social psychology (Vol. 12, pp. 136). Chichester, UK: Wiley. doi: 10.1080/14792772143000003

Shelton, J. N. (2003). Interpersonal concerns in social encounters between majority and minority group members. Group Processes and Intergroup Relations, 6, 171-186. doi: $10.1177 / 1368430203006002003$

Shelton, J. N., Dovidio, J. F., Hebl, M., \& Richeson, J. A. (2009). Prejudice and intergroup interaction. In S. Demoulin, J. Ph. Leyens, \& J. F. Dovidio (Eds.), Intergroup misunderstandings: Impact of divergent social realities (pp. 21-38). New York, NY: Psychology Press. 


\section{NATURAL DISASTERS AND COMMON INGROUP IDENTITY}

Shelton, J. N., \& Richeson, J. A. (2006). Ethnic minorities' racial attitudes and contact experiences with white people. Cultural Diversity and Ethnic Minority Psychology, 12, 149-164. doi: 10.1037/1099-9809.12.1.149

Shelton, J. N., Richeson, J. A, \& Salvatore, J. (2005). Expecting to be the target of prejudice: Implications for interethnic interactions. Personality and Social Psychology Bulletin, 31, 1189-1202. doi: 10.1177/0146167205274894

Shelton, J. N., Richeson, J. A, Salvatore, J., \& Trawalter, S. (2005). Ironic effects of racial bias during interracial interactions. Psychological Science, 16, 397-402. doi: 10.1111/j.0956-7976.2005.01547.x

Shelton, J. N., \& Richeson, J. A, \& Vorauer, J. D. (2006). Threatened identities and interethnic interactions. In M. Hewstone \& W. Stroebe (Eds.), European Review of Social Psychology (Vol. 17, pp. 321-358). New York, NY: Psychology Press. doi: $10.1080 / 10463280601095240$

Shook, N. J., \& Fazio, R. H. (2008). Roommate relationships: A comparison of interracial and same-race living situations. Group Processes and Intergroup Relations, 11, 425437. doi: $10.1177 / 1368430208095398$

Stephan, W. G., \& Stephan, C. W. (1985). Intergroup anxiety. Journal of Social Issues, 41, 157-175. doi: 10.1111/j.1540-4560.1985.tb01134.x

Stephan, W. G., \& Stephan, C. W. (2000). An integrated theory of prejudice. In S. Oskamp (Ed.), Reducing prejudice and discrimination (pp. 23-45). Mahwah, NJ: Erlbaum.

Sun, S., Zagefka, H., \& Goodwin, R. (2013). Predictors of intergroup concern for disaster victims of the japan earthquake. Asian Journal of Social Psychology, 16, 152-157. doi: 10.1111/ajsp. 12023 


\section{NATURAL DISASTERS AND COMMON INGROUP IDENTITY}

Tajfel, H., \& Turner, J. C. (1979). An integrative theory of intergroup conflict. In S. Worchel, \& W. G. Austin (Eds.), The social psychology of intergroup relations (pp. 3347). Monterey, CA: Brooks-Cole.

Taylor, A. B., MacKinnon, D. P., \& Tein, J. -Y. (2008). Tests of the three-path mediated effect. Organizational Research Methods, 11, 241-269. doi:

$10.1177 / 1094428107300344$

Tropp, L. R., \& Pettigrew, T. F. (2005). Relationships between intergroup contact and prejudice among minority and majority status groups. Psychological Science, 16, 951957. doi: 10.1111/j.1467-9280.2005.01643.x

Vallacher, R. R., \& Wegner, D. M. (1987). What do people think they are doing? Action identification and human behavior. Psychological Review, 94, 3-15. doi: 10.1037/0033295X.94.1.3

van Leeuwen, E., \& Täuber, S. (2011). Demonstrating knowledge: The effects of group status on outgroup helping. Journal of Experimental Social Psychology, 47, 147-156. doi: 10.1016/j.jesp.2010.09.008

Vezzali, L., Capozza, D., Mari, S., \& Hichy, Z. (2007). Contact models and intergroup relations in an Italian area bordering on Austria. Testing, Psychometrics, Methodology in Applied Psychology, 14, 1-15.

Vezzali, L., Capozza, D., Stathi, S., \& Giovannini, D. (2012). Increasing outgroup trust, reducing infrahumanization, and enhancing future contact intentions via imagined intergroup contact. Journal of Experimental Social Psychology, 48, 437-440. doi: 10.1016/j.jesp.2011.09.008

Vezzali, L., Giovannini, D., \& Capozza, D. (2010). Longitudinal effects of contact on intergroup relations: The role of majority and minority group membership and 


\section{NATURAL DISASTERS AND COMMON INGROUP IDENTITY}

intergroup emotions. Journal of Community and Applied Social Psychology, 20, 462479. doi: 10.1002/casp.1058

Vezzali, L., Giovannini, D., \& Capozza, D. (2012). Social antecedents of children's implicit prejudice: Direct contact, exteded contact, explicit and implicit teachers' prejudice. European Journal of Developmental Psychology, 9, 569-581. doi: $10.1080 / 17405629.2011 .631298$

Vezzali, L., Stathi, S., Crisp, R. J., Giovannini, D., Capozza, D., \& Gaertner, S. L. (2014). Imagined intergroup contact and common ingroup identity: An integrative approach. Under review.

Vorauer, J. D. (2006). An information search model of evaluative concerns in intergroup interaction. Psychological Review, 113, 862-886. doi: 10.1037/0033-295X.113.4.862

Zagefka, H., Noor, M., \& Brown, R. (2013). Familiarity breeds compassion: Knowledge of disaster areas and willingness to donate money to disaster victims. Applied Psychology: An International Review, 62, 640-654. doi: 10.1111/j.1464-0597.2012.00501.x

Zagefka, H., Noor, M., Brown, R., Hopthrow, T., \& Randsley de Moura, G. (2012). Eliciting donations to disaster victims: Psychological considerations. Asian Journal of Social Psychology, 15, 221-230. doi: 10.1111/j.1467-839X.2012.01378.x

Zagefka, H., Noor, M., Brown, R., Randsley de Moura, G., \& Hopthrow, T. (2011). Donating to disaster victims: Responses to natural and humanly caused events. European Journal of Social Psychology, 41, 353-363. doi: 10.1002/ejsp.781 


\section{NATURAL DISASTERS AND COMMON INGROUP IDENTITY}

Tables

Table 1. Descriptive statistics and correlations among variables for Italian $(N=395)$ and immigrant participants $(N=122)$.

\begin{tabular}{llllllll}
\hline Italian sample & 1 & 2 & 3 & 4 & 5 & 6 \\
\hline
\end{tabular}

1. Perceived disaster threat

2. Two-groups representation $\quad-.17 * * * \quad-$

3. One-group representation $\quad .16 * * * \quad-.30 * * *$

4. Positive outgroup attitudes $\quad .24 * * * \quad-.24 * * * \quad .32 * * *$

5. Contact behavioural intentions $\quad .10^{\dagger} \quad \begin{array}{lllll}-.12 * & .31 * * * & .30 * * * & -\end{array}$

6. Helping behavioural intentions $\quad .11 * \quad-.13 * * \quad .31 * * * \quad .37 * * * \quad .65 * * *$

$\begin{array}{lllllll}M & 2.83 & 2.27 & 3.47 & 7.22 & 3.22 & 3.44 \\ \text { SD } & 0.77 & 1.17 & 0.82 & 2.77 & 0.70 & 0.60\end{array}$

$\begin{array}{lllllll}\text { Immigrant sample } & 1 & 2 & 3 & 4 & 5 & 6\end{array}$

1. Perceived disaster threat

2. Two-groups representation $\quad-.09$

3. One-group representation $\quad-.06 \quad-.22^{*}$

4. Positive outgroup attitudes $\quad-.10 \quad-.05 \quad$.18* $\quad-$

$\begin{array}{lllll}\text { 5. Contact behavioural intentions } & .03 & -.14 & .30 * * * & .10\end{array}$

6. Helping behavioural intentions $\quad .08 \quad-.10 \quad 56 * * \quad .18^{*} \quad .59 * * *$

$\begin{array}{rrrrrrr}M & 2.67 & 2.46 & 3.37 & 8.14 & 3.48 & 3.51 \\ \text { SD } & 0.82 & 1.21 & 0.84 & 2.84 & 0.62 & 0.67\end{array}$

Note. For all measures, the response scale ranges from 1 to 4 , with the exception of outgroup attitudes (scale ranging from 0 to 10 ).

${ }^{\dagger} p \leq .06 . * p \leq .05 . * * p \leq .01 . * * * p \leq .001$. 
NATURAL DISASTERS AND COMMON INGROUP IDENTITY

Table 2. Indirect effects in the Italian and immigrant samples.

\begin{tabular}{|c|c|c|c|c|}
\hline \multicolumn{5}{|l|}{ Italian sample $(N=395)$} \\
\hline Predictor & Indirect process & Criterion variable & $\begin{array}{l}\text { Mean bootstrap } \\
\text { estimate }\end{array}$ & $\begin{array}{l}\text { Percentile confidence } \\
\text { interval }(95 \%)\end{array}$ \\
\hline Perceived disaster threat & Two-groups - positive outgroup attitudes & Contact intentions & 0.0049 & {$[0.0007,0.0121]$} \\
\hline Perceived disaster threat & Two-groups - positive outgroup attitudes & Helping intentions & 0.0056 & {$[0.0008,0.0132]$} \\
\hline Perceived disaster threat & One-group - positive outgroup attitudes & Contact intentions & 0.0086 & {$[0.0017,0.0205]$} \\
\hline Perceived disaster threat & One-group - positive outgroup attitudes & Helping intentions & 0.0099 & {$[0.0021,0.0229]$} \\
\hline Two-groups & Positive outgroup attitudes & Contact intentions & -0.0192 & {$[-0.0413,-0.0039]$} \\
\hline Two-groups & Positive outgroup attitudes & Helping intentions & -0.0218 & {$[-0.0421,-0.0050]$} \\
\hline One-group & Positive outgroup attitudes & Contact intentions & 0.0504 & {$[0.0161,0.0973]$} \\
\hline One-group & Positive outgroup attitudes & Helping intentions & 0.0582 & {$[0.0220,0.1048]$} \\
\hline \multicolumn{5}{|c|}{ Immigrant sample $(N=122)$} \\
\hline Predictor & Indirect process & Criterion variable & $\begin{array}{c}\text { Mean bootstrap } \\
\text { estimate }\end{array}$ & $\begin{array}{l}\text { Percentile confidence } \\
\text { interval }(95 \%)\end{array}$ \\
\hline Perceived disaster threat & Two-groups - positive outgroup attitudes & Contact intentions & 0.00004 & {$[-0.0018,0.0020]$} \\
\hline Perceived disaster threat & Two-groups - positive outgroup attitudes & Helping intentions & 0.0002 & {$[-0.0032,0.0038]$} \\
\hline Perceived disaster threat & One-group - positive outgroup attitudes & Contact intentions & -0.0004 & {$[-0.0054,0.0021]$} \\
\hline Perceived disaster threat & One-group - positive outgroup attitudes & Helping intentions & -0.0012 & {$[-0.0095,0.0035]$} \\
\hline Two-groups & Positive outgroup attitudes & Contact intentions & -0.0004 & {$[-0.0108,0.0090]$} \\
\hline Two-groups & Positive outgroup attitudes & Helping intentions & -0.0020 & {$[-0.0231,0.0141]$} \\
\hline One-group & Positive outgroup attitudes & Contact intentions & 0.0085 & {$[-0.0110,0.0460]$} \\
\hline One-group & Positive outgroup attitudes & Helping intentions & 0.0205 & {$[-0.0044,0.0727]$} \\
\hline
\end{tabular}

Note. Mean bootstrap estimates are based on 2,000 bootstrap samples. 
Table 3. Summary of fit indices of the tested alternative models.

\begin{tabular}{|c|c|c|c|c|c|c|c|c|c|c|c|}
\hline \multicolumn{12}{|c|}{ Italian sample $(N=395)$} \\
\hline Model & Predictor(s) & $\begin{array}{l}\text { Mediator(s) - } \\
\text { Level } 1\end{array}$ & $\begin{array}{l}\text { Mediator(s) - } \\
\text { Level } 2\end{array}$ & Outcome(s) & df & $\chi^{2}$ & $p$ & SRMR & RMSEA & CFI & AIC \\
\hline 1 & $\begin{array}{l}\text { Perceived disaster } \\
\text { threat }\end{array}$ & $\begin{array}{l}\text { Group } \\
\text { representations }\end{array}$ & $\begin{array}{l}\text { Positive outgroup } \\
\text { attitudes }\end{array}$ & $\begin{array}{l}\text { Contact intentions, } \\
\text { helping intentions }\end{array}$ & 2 & .031 & .98 & .002 & .00 & 1.00 & 38.03 \\
\hline 2 & Contact intentions & $\begin{array}{l}\text { Group } \\
\text { representations }\end{array}$ & $\begin{array}{l}\text { Perceived disaster } \\
\text { threat }\end{array}$ & $\begin{array}{l}\text { Positive outgroup } \\
\text { attitudes, helping } \\
\text { intentions }\end{array}$ & 2 & 19.06 & .00 & .034 & .15 & .97 & 56.64 \\
\hline 3 & Helping intentions & Contact intentions & $\begin{array}{l}\text { Group } \\
\text { representations }\end{array}$ & $\begin{array}{l}\text { Perceived disaster } \\
\text { threat, positive } \\
\text { outgroup attitudes }\end{array}$ & 3 & 13.20 & .004 & .040 & .09 & .98 & 48.98 \\
\hline 4 & $\begin{array}{l}\text { Contact } \\
\text { intentions, } \\
\text { helping intentions }\end{array}$ & $\begin{array}{l}\text { Perceived disaster } \\
\text { threat }\end{array}$ & $\begin{array}{l}\text { Positive outgroup } \\
\text { attitudes }\end{array}$ & $\begin{array}{l}\text { Group } \\
\text { representations }\end{array}$ & 2 & 56.84 & .00 & .10 & .25 & .89 & 90.93 \\
\hline \multicolumn{12}{|c|}{ Immigrant sample $(N=122)$} \\
\hline Model & Predictor(s) & $\begin{array}{c}\text { Mediator(s) - } \\
\text { Level } 1 \\
\end{array}$ & $\begin{array}{c}\text { Mediator(s) - } \\
\text { Level } 2\end{array}$ & Outcome(s) & $\mathrm{df}$ & $\chi^{2}$ & $p$ & SRMR & RMSEA & CFI & AIC \\
\hline 1 & $\begin{array}{l}\text { Perceived disaster } \\
\text { threat }\end{array}$ & $\begin{array}{l}\text { Group } \\
\text { representations }\end{array}$ & $\begin{array}{l}\text { Positive outgroup } \\
\text { attitudes }\end{array}$ & $\begin{array}{l}\text { Contact intentions, } \\
\text { helping intentions }\end{array}$ & 2 & 1.59 & .45 & .025 & .00 & 1.00 & 39.58 \\
\hline 2 & Contact intentions & $\begin{array}{l}\text { Group } \\
\text { representations }\end{array}$ & $\begin{array}{l}\text { Perceived disaster } \\
\text { threat }\end{array}$ & $\begin{array}{l}\text { Positive outgroup } \\
\text { attitudes, helping } \\
\text { intentions }\end{array}$ & 2 & 2.64 & .10 & .026 & .05 & .99 & 40.62 \\
\hline 3 & Helping intentions & Contact intentions & $\begin{array}{l}\text { Group } \\
\text { representations }\end{array}$ & $\begin{array}{l}\text { Perceived disaster } \\
\text { threat, positive } \\
\text { outgroup attitudes }\end{array}$ & 3 & 2.69 & .44 & .030 & .00 & 1.00 & 38.66 \\
\hline 4 & $\begin{array}{l}\text { Contact } \\
\text { intentions, } \\
\text { helping intentions }\end{array}$ & $\begin{array}{l}\text { Perceived disaster } \\
\text { threat }\end{array}$ & $\begin{array}{l}\text { Positive outgroup } \\
\text { attitudes }\end{array}$ & $\begin{array}{l}\text { Group } \\
\text { representations }\end{array}$ & 2 & 4.37 & .11 & .05 & .10 & .97 & 42.29 \\
\hline
\end{tabular}


NATURAL DISASTERS AND COMMON INGROUP IDENTITY

Figure captions

Figure 1. Hypothesized path model.

Figure 2. Path model with observed variables for the Italian sample (dotted lines denote nonsignificant paths).

$* p<.05 . * * p<.01 . * * * p<.001$.

Figure 3. Path model with observed variables for the immigrant sample (dotted lines denote nonsignificant paths).

${ }^{\dagger} p<.06 . * p<.05 . * * p<.01 . * * * p<.001$. 
Figure 1

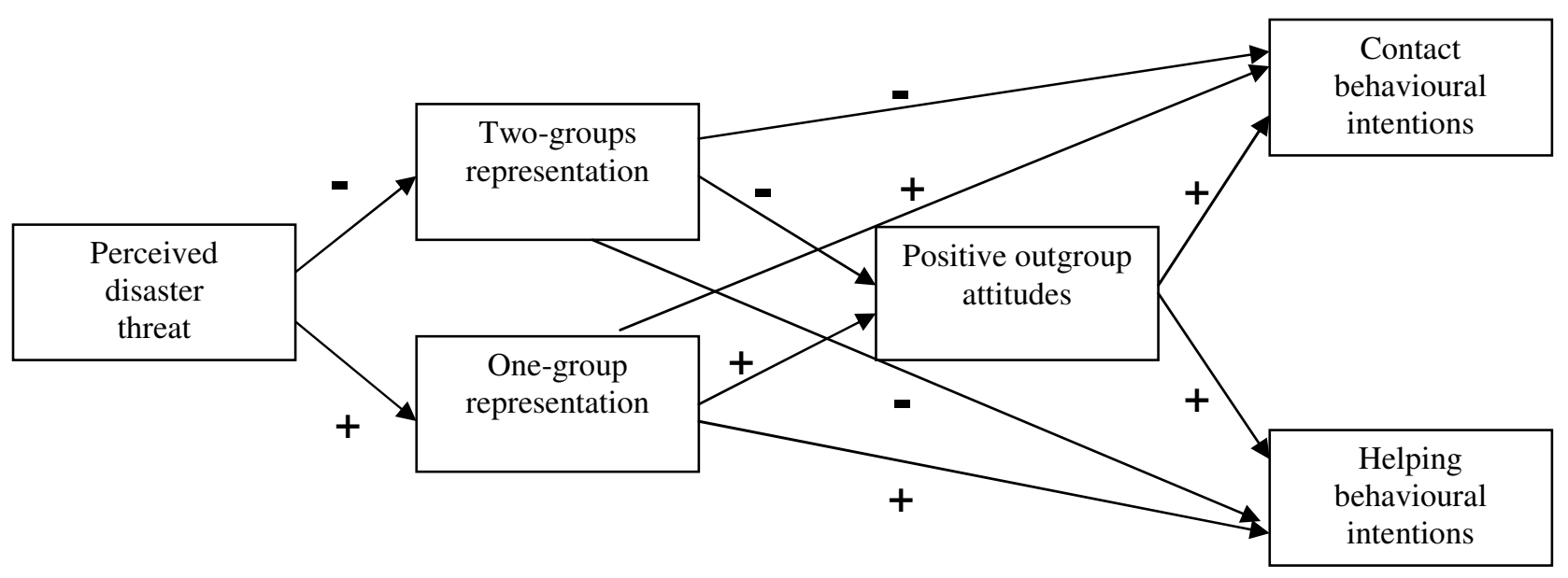


Figure 2

$.17 * * *$

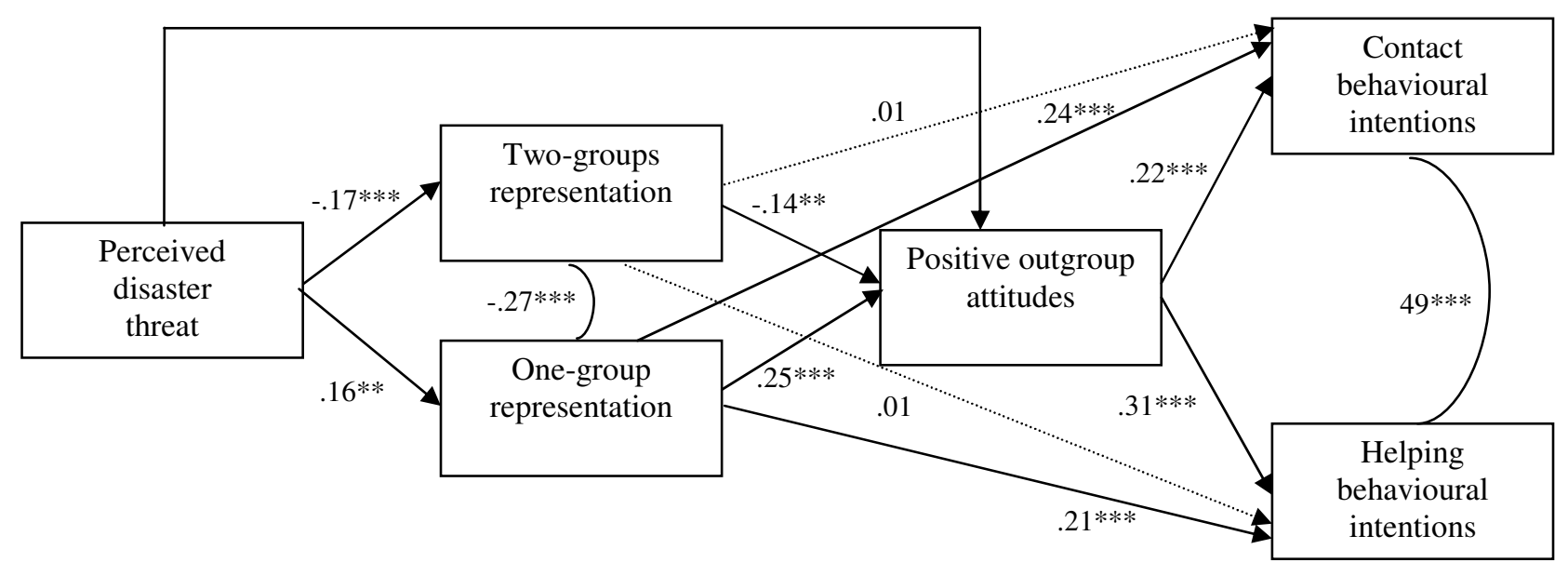




\section{Figure 3}

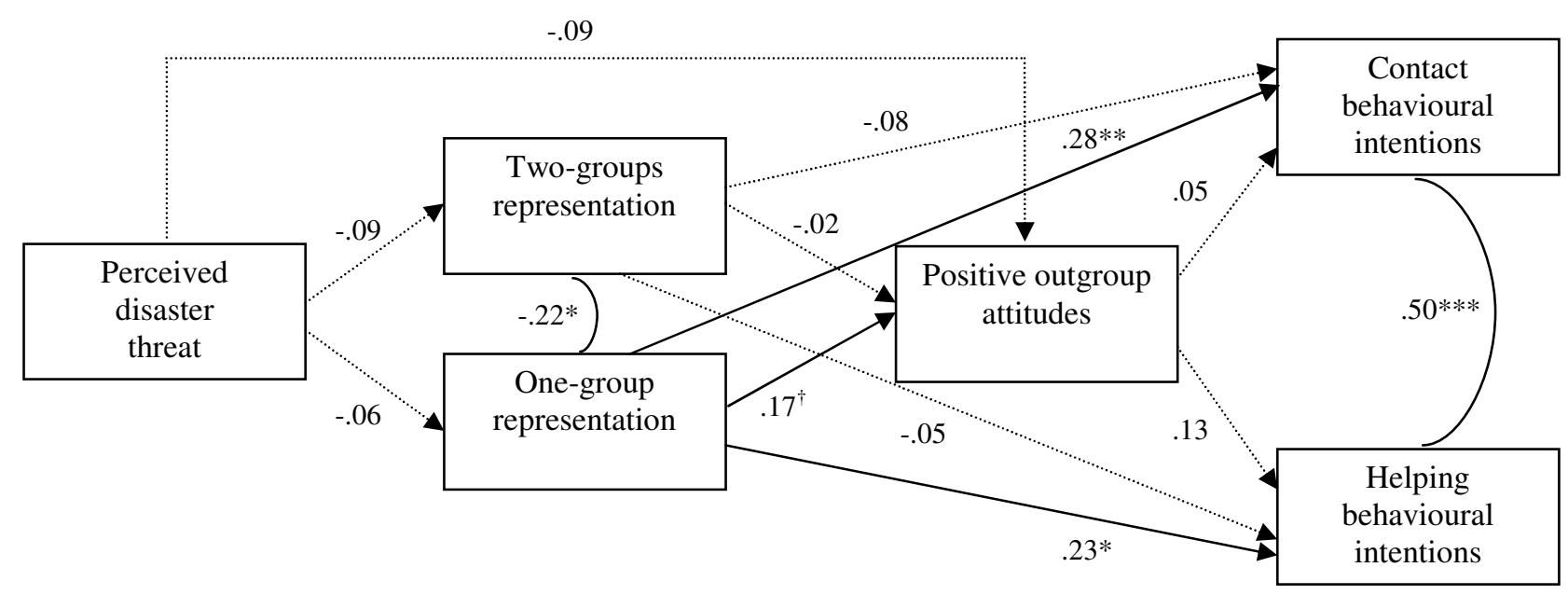

